
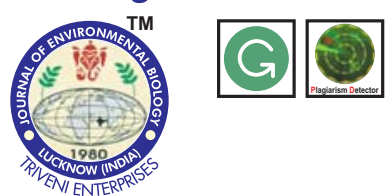

\title{
Interaction of biochemical and nutritional status of nodal sections with rooting success in grape rootstocks
}

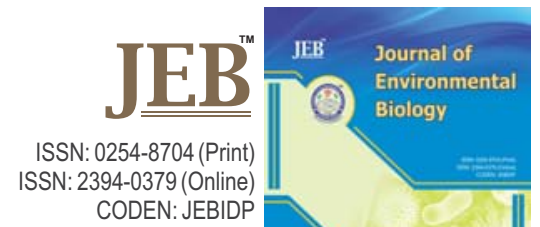

\section{Authors Info \\ R.G. Somkuwar*, M. Bhange, J. Sharma, A.K. Upadhyay and I. Khan}

ICAR - National Research Centre for Grapes, Pune-412 307, India

${ }^{*}$ Corresponding Author Email : rgsgrapes@gmail.com

Key words

Biochemicals,

Cane quality,

Grape rootstocks,

Nutrient status, Rooting success

Publication Info

Paper received: 10.07.2014

Revised received : 21.02 .2015

Re-revised received : 15.06 .2016

Accepted: 13.07.2016
Abstract

Aim : In India, use of grape rootstock in establishing new vineyard started two decades back. To meet the demand of planting material, selection of mature shoots from the mother vine plays an important role. The planting material should have the ability for callusing, rooting, budding and growth. The present experiment was conducted to study vegetative growth, rooting performance, biochemical changes and mineral nutrition in different nodal section of Dogridge and 110-R grape rootstocks after planting under tropical condition.

Methodology : The quality of planting material was assessed by different cane segments. The canes were sectioned into 4- bud segment of both the grape rootstocks. The changes in growth pattern, rooting success, biochemical changes and mineral nutrition level through morphological changes were studied. Canes were later planted in nursery to study the relationship between cane quality and root: shoot growth characteristics.

Results : Noticeable differences were recorded for cane and pith diameter, cane width: pith ratio, moisture percent and dry matter content in canes and also the $\mathrm{C}: \mathrm{N}$ ratio. Dogridge rootstock showed higher rooting percent than 110-R. However, the rootstock 110-R sprouted earlier than Dogridge. The reducing sugar was significantly higher at $9-20$ bud position in both the rootstocks. The nutrient status of canes of both the rootstocks showed significant changes for $\mathrm{N} \%$ and Fe content in different nodal sections.

Interpretation : The cuttings prepared from 1 to $12^{\text {th }}$ internodes in Dogridge and 1 to $16^{\text {th }}$ nodes in $110-R$ had better quality in terms of early sprout, better rooting percent, higher shoot length, shoot diameter and highest amount of reducing sugar, proteins, starch, carbohydrates and well balanced root-shoot growth.

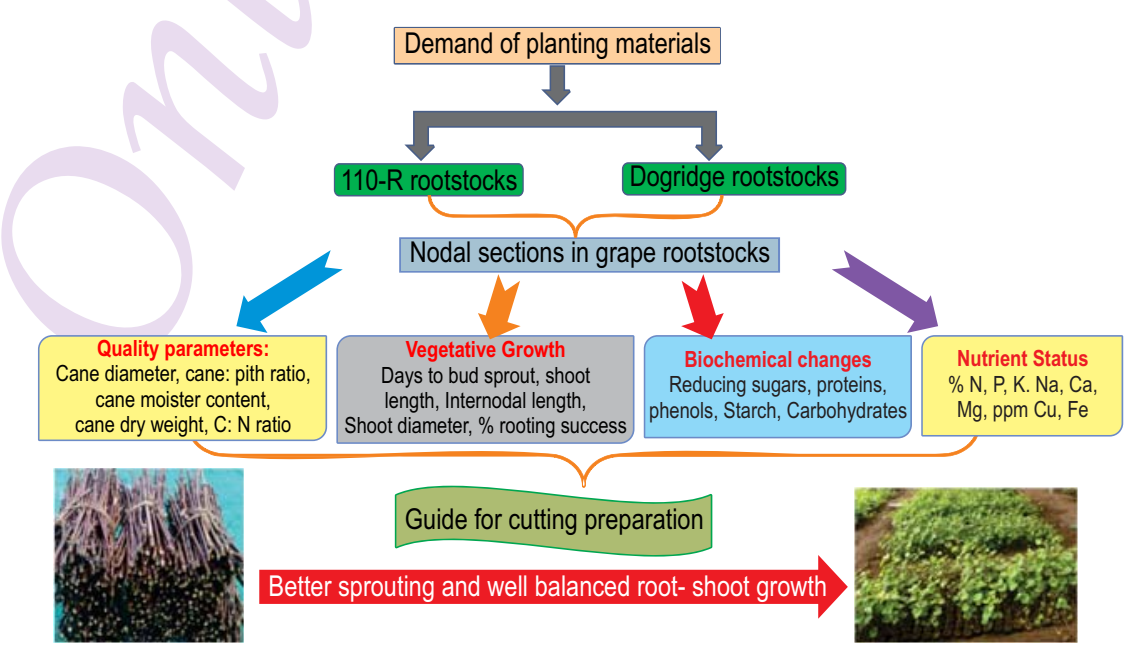




\section{Introduction}

Earlier, the vines grown on their own roots were performing well since the soil and water condition was good. However, with the onset of problems like soil salinity, bad quality water and also the shortage of irrigation water due to drought, the yield and quality of grapes have started declining. This has resulted into reduced fruitfulness of the vine. An increasing occurrence of soil salinity, drought and declining productivity of grapes varieties in India has made use of a suitable rootstocks imperative (Singh and Sharma, 2005). Different rootstocks vary in their capacity to overcome different biotic and abiotic stress. To achieve maximum propagation success, the quality of planting materials plays an important role. Grapes are propagated through hardwood cuttings for which different practices are being followed to achieve maximum success. The quality of propagation material is defined as the ability for callusing, root formation, budding and growth during both callusing period and under nursery conditions (Hunter et al., 2004). The stored food material available in shoot plays an important role in propagation success. In grapes, during propagation through hardwood cuttings, basal 4-nodes cuttings having enough reserve food material and well lignified showed better rooting percent and sprouted earlier with maximum shoots than the apical cuttings (Dardeniz et al., 2008). Cane maturity is an important parameter for developing roots and shoots after planting. The lignified and well matured canes develop better root and shoots than the weak and immature canes (Hunter et al., 2004). Several studies have reported the quality of cane for propagation could be determined by using the ratio of cane width/pith and phloem+xylem/pith values (Dardeniz et al., 2008 and Hunter et al., 2004). Rooting ability of cuttings differ with the species, Indole-3-butyric acid concentration and biochemical composition of the mother vines (Satisha et al., 2007). Carbohydrates stored in cane indicates health and vigour of vine during growth period (Somkuwar et al., 2011). High carbohydrates and nitrogen reserves such as starch increases the potential for callusing. Dardeniz et al. (2007, 2008) determined the best time and cane sections of 140-Ru to collect and use for propagation purpose.The present research was conducted to study the vegetative growth, rooting performance, biochemical changes and mineral nutrition in different nodal sections of Dogridge and 110-R grape rootstocks after planting under tropical condition.

\section{Materials and Methods}

The present study was carried out during the year 20112013 on cuttings of two different rootstocks such as Dogridge (Vitis champinii) and $110-\mathrm{R}$ (Vitis berlandieri $\times$ Vitis rupestris). The mother vines of these rootstocks were maintained in the nursery of ICAR-National Research Centre for Grapes, Pune. The experiment was conducted in randomized block design consisting of six treatments as nodal segments. Each treatment consisted of 20 plants and was replicated four times totalling 80 plants under each rootstock. Canes were randomly selected on the basis of uniform thickness, maturity with proper lignification and desired length. The canes were sectioned into 4-node segments from base to tip of the canes (1-4, 5-8, 9-12, 13-16, 1720 and 21-24) as an individual treatment. From each treatment, random cuttings were taken to study cane characters such as cane diameter, pith diameter, ratio of cane diameter/pith diameter, cane fresh and dry weight in different nodal segments. The samples were also used to study the biochemical and nutritional status in different nodal segment. The selected cuttings were soaked in water for $24 \mathrm{hrs}$ to leach out the rooting inhibitors available on the cuttings. Fresh slanting cut was then taken at the basal portion of the cuttings so as to expose maximum area for rooting. The cut end was then dipped in 2000 ppm IBA for about $60 \mathrm{sec}$ and planted in black polythene bags of 5" X 7" size (one litre capacity) filled with potting mixture of soil, sand and compost (2:1:1). Immediately after planting, the poly bags were watered thoroughly. All the cultural operations like weeding and plant protection were carried out at different growth stages during the period of experiment.

Biochemical compositions: Extraction was carried out by following the method of Sadashivam and Manickam (1992). A0.5 $\mathrm{g}$ of crushed sample was extracted using $10 \mathrm{ml} 80 \%$ aqueous methanol by overnight shaking at room temperature on a mechanical shaker. The supernatant was collected and residues were re-extracted twice under similar conditions. Finally, the supernatant obtained at each step of extraction was pulled together and used as a stock for estimation of carbohydrate, total phenol and reducing sugars. The residues were extracted again at $40^{\circ} \mathrm{C}$ with $52 \%$ perchloric acid and deionized water (two times, 30 minutes each) and the supernatant was used as a stock for starch estimation.

Carbohydrate and starch was estimated by Anthrone method, while reducing sugar was estimated by di-nitrosalicylic acid method. Total phenolic content was estimated by FolinCiocalteu reagent by measuring the absorbance of the reaction mixture at $650 \mathrm{~nm}$ as suggested by Sadashivam and Manickam (1992). The results obtained were expressed as catechol equivalent $\left(\mathrm{mg} \mathrm{g}^{-1}\right)$ of crushed sample.

For protein estimation, $0.5 \mathrm{~g}$ of crushed sample was homogenized in $0.1 \mathrm{M}$ phosphate buffer $(\mathrm{pH} 7.0)$. The homogenate was centrifuged at $5000 \mathrm{rpm}$ for $15 \mathrm{~min}$ at $40^{\circ} \mathrm{C}$ and supernatant was used as a source for protein estimation by the method of Lowery et al. (1951).

Nutrient status: Nutrient contents was estimated by the procedure of Sharma et al. (2010). Fully matured cane segments from mother vines of Dogridge and $110-R$ rootstocks were cut into pieces and dried in hot air oven at $65^{\circ} \mathrm{C}$ for $48 \mathrm{hrs}$. The segments were then subjected to grinding, sieved, and fine powder was used for analysis of major nutrients. Among the nutrients, nitrogen 
Table 1 : Effect of nodal sections on quality parameters of Dogridge and 110-R grape rootstocks

\begin{tabular}{|c|c|c|c|c|c|c|c|c|}
\hline $\begin{array}{l}\text { Nodal } \\
\text { sections }\end{array}$ & $\begin{array}{l}\text { Cane diameter } \\
(\mathrm{mm})\end{array}$ & $\begin{array}{l}\text { Pith diameter } \\
(\mathrm{mm})\end{array}$ & $\begin{array}{l}\text { Cane width: } \\
\text { pith }\end{array}$ & $\begin{array}{l}\text { Cane moisture } \\
\text { content }(\%)\end{array}$ & $\begin{array}{l}\text { Cane fresh } \\
\text { weight (g) }\end{array}$ & $\begin{array}{l}\text { Cane dry } \\
\text { weight (g) }\end{array}$ & $\begin{array}{l}\text { Cane dry } \\
\text { matter(\%) }\end{array}$ & $\begin{array}{l}\mathrm{C}: \mathrm{N} \\
\text { ratio }\end{array}$ \\
\hline \multicolumn{9}{|l|}{ Dogridge } \\
\hline $1-4$ & $11.5^{\mathrm{a}}$ & $2.35^{\mathrm{a}}$ & $4.89^{\mathrm{a}}$ & $42.70^{\mathrm{ab}}$ & $24.00^{\mathrm{a}}$ & $10.25^{\mathrm{a}}$ & $57.29^{b}$ & $18.40^{b}$ \\
\hline $5-8$ & $10.8^{b}$ & $2.25^{\mathrm{a}}$ & $4.80^{\mathrm{ab}}$ & $41.91^{b}$ & $23.50^{\mathrm{ab}}$ & $9.850^{b}$ & $58.08^{b}$ & $19.32^{\mathrm{a}}$ \\
\hline $9-12$ & $9.50^{c}$ & $2.01^{b}$ & $4.72^{b}$ & $42.12^{b}$ & $23.05^{\mathrm{bc}}$ & $9.709^{b}$ & $66.55^{\mathrm{a}}$ & $18.55^{b}$ \\
\hline $13-16$ & $8.00^{d}$ & $1.78^{c}$ & $4.70^{b}$ & $42.17^{b}$ & $23.00^{\mathrm{bc}}$ & $9.700^{b}$ & $57.82^{b}$ & $17.75^{\circ}$ \\
\hline $17-20$ & $7.20^{\circ}$ & $1.70^{\circ}$ & $4.23^{c}$ & $43.48^{\mathrm{a}}$ & $22.65^{c}$ & $9.850^{b}$ & $56.51^{b}$ & $16.36^{d}$ \\
\hline $21-24$ & $6.50^{f}$ & $1.65^{\circ}$ & $3.93^{d}$ & $43.05^{\mathrm{ab}}$ & $21.25^{\mathrm{d}}$ & $9.150^{\circ}$ & $56.94^{b}$ & $12.43^{e}$ \\
\hline CV\% & 2.36 & 3.24 & 1.40 & 1.51 & 1.36 & 1.36 & 2.10 & 1.89 \\
\hline LSD $5 \%$ & 0.383 & 0.116 & 0.115 & - & 0.568 & 0.241 & 1.965 & 0.589 \\
\hline Significance & ** & $* *$ & $* *$ & NS & $* *$ & $* *$ & $* *$ & $* *$ \\
\hline \multicolumn{9}{|l|}{$110-R$} \\
\hline $1-4$ & $10.0^{a}$ & $2.20^{a}$ & $4.54^{b}$ & $40.79^{\mathrm{a}}$ & $23.80^{\mathrm{a}}$ & $9.710^{\mathrm{a}}$ & $59.20^{\mathrm{bc}}$ & $14.81^{\mathrm{bc}}$ \\
\hline $5-8$ & $10.0^{a}$ & $2.20^{a}$ & $4.54^{b}$ & $40.76^{\mathrm{a}}$ & $23.82^{\mathrm{a}}$ & $9.710^{\mathrm{a}}$ & $59.23^{\mathrm{bac}}$ & $16.47^{\mathrm{a}}$ \\
\hline $9-12$ & $9.60^{b}$ & $1.95^{b}$ & $4.92^{\mathrm{a}}$ & $39.10^{\mathrm{bc}}$ & $22.65^{b}$ & $8.860^{b}$ & $60.88^{a}$ & $15.20^{b}$ \\
\hline $13-16$ & $8.25^{c}$ & $1.71^{\mathrm{c}}$ & $4.82^{\mathrm{a}}$ & $39.93^{\mathrm{ab}}$ & $22.10^{b}$ & $8.825^{b}$ & $60.06^{\text {bac }}$ & $14.44^{\text {cd }}$ \\
\hline $17-20$ & $7.40^{d}$ & $1.65^{c}$ & $4.48^{b}$ & $38.57^{\circ}$ & $21.00^{\circ}$ & $8.250^{\circ}$ & $60.71^{a b}$ & $14.55^{\mathrm{cd}}$ \\
\hline $21-24$ & $6.00^{\circ}$ & $1.55^{d}$ & $3.87^{c}$ & $39.28^{\mathrm{ab}}$ & $19.50^{d}$ & $7.100^{d}$ & $58.46^{c}$ & $14.21^{\mathrm{d}}$ \\
\hline CV\% & 2.26 & 1.78 & 1.59 & 1.33 & 1.42 & 1.46 & 1.53 & 1.58 \\
\hline LSD $5 \%$ & 0.352 & 0.060 & 0.131 & 0.963 & 0.572 & 0.233 & 1.671 & 0.431 \\
\hline Significance & ** & $* *$ & ** & * & ** & ** & * & ** \\
\hline
\end{tabular}

was estimated by nitrogen auto analyser following Kjeldahl method using Gerhardt Distillation Unit (Vapodest 30), after digesting the samples on a digestion system. Phosphorous content in cane was estimated using UV- visible spectrophotometer, Evolution, 201, Thermo Scientific, USA, while potash content was estimated by digital flame photometer, JENWAY, UK. The nutrient content in cane was expressed as \% dry weight basis.

Growth parameters: The observations on days taken for sprouting were recorded on daily basis and the percent success was recorded at $75^{\text {th }}$ day after planting. The growth parameters like shoot length, shoot diameter, inter nodal length and rooting per cent were recorded at $90^{\text {th }}$ day after pruning.

Statistical analysis : All the calculations were performed using the GLM procedure of SAS System software, version 9.3 (SAS, 2004).

\section{Results and Discussion}

Cane diameter of Dogridge and 110-R rootstock significantly decreased from base to the tip. Decrease in pith diameter also followed the same pattern in the cuttings of both the rootstocks (Table 1). The increase in cane diameter at the basal portion of cuttings (1-4 buds) might be due to the accumulation of large amount of reserve food materials in the cells. Dardeniz et al. (2008) also reported that upper section of cane had less reserve with lower quality. The cane width/pith ratio was significantly different from base to tip in both the rootstocks. The nodal segment from 1-4 to 17-20 in the canes of Dogridge had wider ratio as compared with the nodes of $110-R$ rootstock. However, the cane segment from 9-12 and 13-16 nodes in 110-R rootstock showed more ratio than other nodes. The differences in cane width/pith ratio might be due to development of vascular bundle in canes. Dardeniz et al. (2007) also used the cane width/pith and phloem + xylem/pith ratio to determine the cane quality. The data on cane moisture content was non-significant for Dogridge rootstock while slight differences in $110-R$ were recorded.

Cane fresh weight and dry weight decreased from base to tip in both the rootstocks. The highest fresh and dry weight was recorded with basal nodes of cane (1-4) in both the rootstocks, while the least amount of fresh and dry weight was recorded with apical portion (21-24). The increase in fresh and dry weight of cuttings might be due to the availability of more reserve foods in the tissues at the basal end. The results obtained in the present investigation for fresh weight and dry weight confirms the findings of our earlier work where dry matter content significantly differed among rootstocks in all the vine parts (Somkuwar et al., 2009).

$\mathrm{C} / \mathrm{N}$ ratio of cane was considered as most significant indicator for lignification. The $\mathrm{C} / \mathrm{N}$ ratio was higher in basal node segments of both the rootstocks (1-8 nodes) while least towards the apical node segments. The better rooting percent of hardwood cuttings might be due to higher $\mathrm{C} / \mathrm{N}$ ratio (Satisha et al., 2007; Turkmen et al., 2011).

Vegetative growth plays an important role in obtaining appropriate shoot diameter and number of cuttings required for 
Table 2 : Effect of nodal sections on vegetative parameters of Dogridge and 110-R grape rootstocks

\begin{tabular}{|c|c|c|c|c|c|c|c|c|c|c|}
\hline \multirow[t]{2}{*}{ Nodal Sections } & \multicolumn{2}{|c|}{ Days taken for bud sprout } & \multicolumn{2}{|c|}{ Shoot length $(\mathrm{cm})$} & \multicolumn{2}{|c|}{ Inter nodal length $(\mathrm{cm})$} & \multicolumn{2}{|c|}{ Shoot diameter (mm) } & \multicolumn{2}{|c|}{$\%$ rooting success } \\
\hline & S-1 & S-2 & S-1 & S-2 & S-1 & S-2 & S-1 & S-2 & S-1 & S-2 \\
\hline \multicolumn{11}{|l|}{ Dogridge } \\
\hline $1-4$ nodes & $11.0^{\mathrm{a}}$ & 11.50 & $35.0^{\mathrm{a}}$ & $38.0^{\mathrm{a}}$ & $4.8^{\mathrm{d}}$ & $4.5^{\mathrm{e}}$ & $5.6^{\mathrm{a}}$ & $5.8^{\mathrm{a}}$ & $88.5^{\mathrm{a}}$ & $90.0^{\mathrm{a}}$ \\
\hline $5-8$ nodes & $10.0^{b}$ & 10.0 & $35.0^{\mathrm{a}}$ & $38.5^{\mathrm{a}}$ & $5.0^{\circ}$ & $4.8^{d}$ & $5.6^{\mathrm{a}}$ & $5.8^{\mathrm{a}}$ & $87.0^{\mathrm{a}}$ & $90.0^{\mathrm{a}}$ \\
\hline $9-12$ nodes & $9.5^{c}$ & 9.8 & $35.0^{\mathrm{a}}$ & $38.5^{\mathrm{a}}$ & $5.3^{b}$ & $5.0^{\circ}$ & $5.4^{\mathrm{b}}$ & $5.8^{\mathrm{a}}$ & $82.0^{\mathrm{b}}$ & $87.30^{\mathrm{bc}}$ \\
\hline $13-16$ nodes & $8.0^{d}$ & 8.5 & $30.0^{\circ}$ & $36.0^{b}$ & $5.8^{\mathrm{a}}$ & $5.5^{\mathrm{c}}$ & $5.5^{\mathrm{ab}}$ & $5.5^{b}$ & $83.0^{\mathrm{b}}$ & $86.50^{\circ}$ \\
\hline $17-20$ nodes & $7.5^{\mathrm{e}}$ & 8.0 & $31.0^{\mathrm{b}}$ & $36.0^{\mathrm{b}}$ & $5.3^{b}$ & $5.3^{\mathrm{b}}$ & $4.6^{\mathrm{c}}$ & $5.5^{\mathrm{b}}$ & $84.0^{\mathrm{b}}$ & $89.20^{\mathrm{ab}}$ \\
\hline $21-24$ nodes & $7.0^{\dagger}$ & 7.0 & $30.0^{\circ}$ & $35.0^{\mathrm{b}}$ & $5.2^{\mathrm{b}}$ & $5.1^{\circ}$ & $4.6^{c}$ & $5.4^{\mathrm{b}}$ & $87.0^{\mathrm{a}}$ & $90.10^{a}$ \\
\hline CV \% & 2.420 & 2.380 & 1.659 & 1.555 & 1.528 & 1.597 & 1.934 & 1.520 & 1.561 & 1.511 \\
\hline LSD $5 \%$ & 0.388 & 0.395 & 0.986 & 1.046 & 0.145 & 0.146 & 0.183 & 0.155 & 2.421 & - \\
\hline Significance & $* *$ & $* *$ & $* *$ & $* *$ & $* *$ & $* *$ & $* *$ & * & $* *$ & NS \\
\hline \multicolumn{11}{|l|}{$110-R$} \\
\hline $1-4$ nodes & $10.0^{\mathrm{a}}$ & $10.00^{a}$ & $33.0^{b}$ & $36.0^{\mathrm{a}}$ & $4.5^{b}$ & $4.5^{\mathrm{d}}$ & $5.5^{a}$ & $5.7^{\mathrm{a}}$ & $88.00^{\mathrm{a}}$ & $88.50^{\mathrm{a}}$ \\
\hline $5-8$ nodes & $9.0^{b}$ & $10.20^{a}$ & $34.0^{\mathrm{a}}$ & $37.0^{\mathrm{a}}$ & $4.7^{\mathrm{a}}$ & $4.5^{\mathrm{d}}$ & $5.5^{\mathrm{a}}$ & $5.7^{\mathrm{a}}$ & $88.50^{a}$ & $88.00^{a}$ \\
\hline $9-12$ nodes & $9.0^{\mathrm{b}}$ & $9.50^{b}$ & $34.0^{\mathrm{a}}$ & $37.5^{\mathrm{a}}$ & $4.7^{\mathrm{a}}$ & $4.7^{\mathrm{bc}}$ & $5.4^{a b}$ & $5.8^{\mathrm{bc}}$ & $85.00^{b}$ & $87.50^{\mathrm{a}}$ \\
\hline $13-16$ nodes & $8.0^{\circ}$ & $9.50^{\mathrm{b}}$ & $30.5^{\circ}$ & $36.6^{\mathrm{ab}}$ & $4.5^{\mathrm{b}}$ & $4.9^{\mathrm{a}}$ & $5.4^{\mathrm{ab}}$ & $5.3^{\mathrm{c}}$ & $85.00^{\mathrm{b}}$ & $87.00^{\mathrm{ab}}$ \\
\hline $17-20$ nodes & $8.0^{\circ}$ & $9.0^{\circ}$ & $29.0^{d}$ & $37.0^{\mathrm{a}}$ & $4.1^{\circ}$ & $4.8^{\mathrm{ab}}$ & $5.3^{\mathrm{b}}$ & $5.2^{\mathrm{ab}}$ & $84.00^{b}$ & $85.00^{b}$ \\
\hline $21-24$ nodes & $7.0^{\mathrm{d}}$ & $7.8^{\mathrm{d}}$ & $29.5^{\mathrm{d}}$ & $36.0 \mathrm{~b}$ & $4.1^{\circ}$ & $4.6^{\mathrm{dc}}$ & $5.4^{\mathrm{ab}}$ & $4.9^{\mathrm{a}}$ & $84.00^{b}$ & $85.20^{b}$ \\
\hline CV\% & 1.976 & 2.065 & 1.631 & 1.492 & 1.547 & 1.487 & 1.490 & 1.629 & 1.387 & 1.232 \\
\hline LSD $5 \%$ & 0.305 & 0.350 & 0.939 & - & 0.124 & 0.126 & 0.146 & 2.442 & 2.163 & 2.242 \\
\hline Significance & $* *$ & $* *$ & $* *$ & NS & $* *$ & * & ** & $* *$ & * & $*$ \\
\hline
\end{tabular}

S-1 (season 1) and S-2 (season 2); NS (non-significant)

multiplication. Significant changes were recorded for all the vegetative parameters such as number of days taken for bud sprout, shoot length, inter nodal length and shoot diameter (except \% rooting success) of Dogridge rootstock. The cuttings of $110-R$ rootstock were early to sprout than the cuttings of Dogridge rootstock. The period for bud sprouts increased during the next year with maximum period taken for bud sprouts at the basal node segments while the period for bud sprouts at lateral node segment was less. However, in both the rootstocks, the period for bud sprout was more when the cuttings from basal portion were selected as compared to the apical ends. Similar trends were also observed for shoot length. The cuttings from basal sections exhibited higher shoot length than the lateral nodes in both the rootstocks. The shoot length in the next season was increased over previous year in both the rootstocks. However, the differences for shoot length in 110-R were non-significant in the next year of study. The early bud sprout and increased vigour through shoot length in cuttings of the rootstock may be attributed to the increased polyphenol oxidase activity in their buds as reported by Satisha et al. (2012). The change in enzyme activity seems to be an indicator of the end of dormancy and the start of growth, as described by Citadin et al. (2011).

The inter nodal length and shoot diameter plays an important role in reserving the food material required for further growth after planting. Inter nodal length at the basal nodes in Dogridge rootstock was less as compared to apical nodes of the shoots. The length subsequently increased in between the nodes. The trend of increased inter nodal length changed at $16^{\text {th }}$ nodes and there was decrease in inter nodes in both the rootstocks. It was observed that with increase in shoot length, inter nodal length also increased. The data recorded for shoot diameter varied significantly among the different nodal sections in both the rootstocks studied. Dogridge rootstock had more shoot diameter than 110-R, however, diameter at basal end was more in 110-R than Dogridge rootstock. The increased vigor of the cuttings is attributed to more vigorous growth, which is evident from the increased diameter. The increase in vegetative growth in Dogridge through shoot length, internodal length and shoot diameter might be due to the availability of high amount of storage which helped the plant to grow vigorously. The findings of the present study is in confirmation with the findings of Somkuwar et al. (2009) who reported that the presence of starch, proteins and carbohydrates in rooted plants acts as an energy source for further plant growth. The biochemical changes in different parts of vine during bud break have also been studied by Sivaci (2006).In our study, the amount of carbohydrate present in basal portions of nodal sections supports early rooting and bud sprouts. This may supports to select the nodal sections for multiplication.

The data recorded for percent rooting among the different nodal segments of canes of both rootstocks are presented in Table 2. Highest \% rooting success was found with basal node segments in both the rootstocks, while it decreased in apical 
Table 3 : Effect of nodal sections on biochemical changes inDogridge and 110-R grape rootstocks

\begin{tabular}{|c|c|c|c|c|c|c|c|c|c|c|}
\hline \multirow[t]{2}{*}{ Nodal Sections } & \multicolumn{2}{|c|}{ Reducing Sugar (mg g $\left.{ }^{-1}\right)$} & \multicolumn{2}{|c|}{ Protein $\left(\mathrm{mg} \mathrm{g}^{-1}\right)$} & \multicolumn{2}{|c|}{ Phenols (mg g ${ }^{-1}$ ) } & \multicolumn{2}{|c|}{ Starch $\left(\mathrm{mg} \mathrm{g}^{-1}\right)$} & \multicolumn{2}{|c|}{ Total Carbohydrate $\left(\mathrm{mg} \mathrm{g}^{-1}\right)$} \\
\hline & S-1 & S-2 & S-1 & S-2 & S-1 & S-2 & S-1 & S-2 & S-1 & S-2 \\
\hline \multicolumn{11}{|l|}{ Dogridge } \\
\hline $1-4$ nodes & $80.01^{\mathrm{a}}$ & $85.50^{\text {cd }}$ & $60.71^{\mathrm{ab}}$ & $65.50^{\circ}$ & $17.52^{\mathrm{a}}$ & $18.32^{\mathrm{a}}$ & $20.10^{b}$ & $22.15^{\mathrm{c}}$ & $43.04^{b}$ & $51.55^{\mathrm{b}}$ \\
\hline 5-8 nodes & $84.86^{c}$ & $86.75^{\mathrm{bc}}$ & $59.44^{\mathrm{ab}}$ & $65.70^{\circ}$ & $17.49^{\mathrm{a}}$ & $18.50^{\mathrm{a}}$ & $20.10^{b}$ & $24.30^{\mathrm{a}}$ & $45.16^{\mathrm{a}}$ & $54.33^{\mathrm{a}}$ \\
\hline $9-12$ nodes & $96.74^{\mathrm{a}}$ & $89.00^{b}$ & $61.16^{\mathrm{a}}$ & $68.75^{\mathrm{b}}$ & $17.81^{\mathrm{a}}$ & $18.50^{\mathrm{a}}$ & $21.15^{\mathrm{a}}$ & $23.10^{b}$ & $41.80^{b}$ & $54.50^{\mathrm{a}}$ \\
\hline $13-16$ nodes & $92.38^{\mathrm{b}}$ & $95.00^{\mathrm{a}}$ & $58.79^{b}$ & $73.15^{\mathrm{a}}$ & $17.50^{\mathrm{a}}$ & $18.31^{\mathrm{a}}$ & $19.10^{\circ}$ & $24.15^{\mathrm{a}}$ & $38.23^{\circ}$ & $55.50^{\mathrm{a}}$ \\
\hline $17-20$ nodes & $84.62^{c}$ & $83.50^{d}$ & $55.02^{c}$ & $62.10^{\mathrm{d}}$ & $14.11^{\mathrm{b}}$ & $18.35^{\mathrm{a}}$ & $18.50^{\mathrm{d}}$ & $20.15^{d}$ & $36.20^{\mathrm{d}}$ & $51.00^{\mathrm{b}}$ \\
\hline 21-24 nodes & $69.35^{\mathrm{e}}$ & $72.20^{\mathrm{e}}$ & $42.53^{d}$ & $61.00^{d}$ & $14.10^{\mathrm{b}}$ & $18.30^{\mathrm{a}}$ & $18.00^{d}$ & $18.24^{\mathrm{e}}$ & $29.47^{\circ}$ & $38.15^{\circ}$ \\
\hline CV \% & 1.838 & 1.932 & 2.109 & 1.680 & 1.907 & 1.473 & 1.481 & 2.171 & 2.408 & 2.254 \\
\hline LSD $5 \%$ & 2.831 & 2.999 & 2.160 & 2.018 & 0.569 & - & 0.525 & 0.869 & 1.708 & 2.085 \\
\hline Significance & $* *$ & $* *$ & $* *$ & $* *$ & $* *$ & NS & $* *$ & $* *$ & $* *$ & $* *$ \\
\hline \multicolumn{11}{|l|}{$110-R$} \\
\hline $1-4$ nodes & $79.77^{\circ}$ & $81.80^{d}$ & $72.55^{c}$ & $73.15^{\mathrm{bc}}$ & $13.91^{\mathrm{c}}$ & $15.15^{b}$ & $25.03^{\mathrm{ab}}$ & $27.10^{\mathrm{a}}$ & $46.30^{c d}$ & $45.50^{b}$ \\
\hline $5-8$ nodes & $82.50^{\mathrm{ab}}$ & $83.15^{\mathrm{cd}}$ & $75.00^{\mathrm{ab}}$ & $75.00^{b}$ & $15.90^{\mathrm{a}}$ & $16.10^{\mathrm{a}}$ & $25.00^{\mathrm{ab}}$ & $27.20^{\mathrm{a}}$ & $48.25^{\mathrm{a}}$ & $47.30^{\mathrm{a}}$ \\
\hline $9-12$ nodes & $85.00^{\mathrm{a}}$ & $84.10^{\mathrm{bc}}$ & $76.50^{\mathrm{a}}$ & $77.50^{\mathrm{a}}$ & $14.80^{\mathrm{b}}$ & $16.50^{\mathrm{a}}$ & $25.00^{\mathrm{ab}}$ & $27.10^{a}$ & $48.25^{\mathrm{a}}$ & $47.50^{\mathrm{a}}$ \\
\hline $13-16$ nodes & $81.23^{b}$ & $86.50^{\mathrm{a}}$ & 75.18ab & $72.15^{\mathrm{cd}}$ & $13.80^{\circ}$ & $16.10^{\mathrm{a}}$ & $24.15^{c}$ & $25.20^{\mathrm{b}}$ & $47.30^{\mathrm{ab}}$ & $45.13^{\mathrm{a}}$ \\
\hline $17-20$ nodes & $71.50^{\circ}$ & $86.10^{\mathrm{ab}}$ & 74.50 & $71.00^{d}$ & $13.50^{c}$ & $16.10^{\mathrm{a}}$ & $25.50^{\mathrm{a}}$ & $26.50^{\mathrm{a}}$ & $45.00^{c d}$ & $45.20^{b}$ \\
\hline $21-24$ nodes & $65.00^{\mathrm{d}}$ & $86.50^{\mathrm{a}}$ & 73.50 & $71.00^{d}$ & $14.50^{\mathrm{b}}$ & $16.12^{\mathrm{a}}$ & $24.50^{\mathrm{bc}}$ & $26.50^{\mathrm{a}}$ & $44.50^{d}$ & $45.00^{b}$ \\
\hline CV\% & 1.869 & 1.478 & 1.474 & 1.427 & 1.727 & 1.457 & 1.505 & 1.451 & 1.572 & 1.492 \\
\hline LSD 5\% & 2.635 & - & - & 1.903 & 0.452 & - & 0.681 & - & 1.333 & 1.247 \\
\hline Significance & $* *$ & NS & NS & * & $* *$ & NS & NS & NS & * & NS \\
\hline
\end{tabular}

S-1 (season 1) and S2-2 (season 2); NS (non-significant)

Table 4 : Effect of nodal sections on nutrient status of Dogridge and 110-R grape rootstocks

\begin{tabular}{|c|c|c|c|c|c|c|c|c|c|c|c|c|c|c|c|c|}
\hline \multirow{2}{*}{$\begin{array}{l}\text { Nodal } \\
\text { sections }\end{array}$} & \multicolumn{2}{|c|}{$\mathrm{N}(\%)$} & \multicolumn{2}{|c|}{$P(\%)$} & \multicolumn{2}{|c|}{$\mathrm{K}(\%)$} & \multicolumn{2}{|c|}{$\mathrm{Na}(\%)$} & \multicolumn{2}{|c|}{$\mathrm{Ca}(\%)$} & \multicolumn{2}{|c|}{$M g(\%)$} & \multicolumn{2}{|c|}{$\mathrm{Cu}(\mathrm{ppm})$} & \multicolumn{2}{|c|}{$\mathrm{Fe}(\mathrm{ppm})$} \\
\hline & S-1 & S-2 & S-1 & S-2 & S-1 & S-2 & S-1 & S-2 & S-1 & S-2 & S-1 & S-2 & S-1 & S-2 & S-1 & S-2 \\
\hline \multicolumn{17}{|l|}{ Dogridge } \\
\hline & $252^{\text {cd }}$ & $0.262^{b}$ & $0.181^{\mathrm{a}}$ & 0.187 & $0.483^{a}$ & $0.450^{\mathrm{a}}$ & $0.120^{\circ}$ & $0.125^{\mathrm{ab}}$ & $0.704^{a}$ & $0.640^{\mathrm{a}}$ & $0.170^{b}$ & $0.200^{b}$ & $13.667^{\mathrm{a}}$ & $15.55^{\mathrm{a}}$ & $28.467^{\mathrm{d}}$ & $30.51^{b c}$ \\
\hline & $250^{d}$ & $0.265^{b}$ & $181^{\mathrm{a}}$ & 0.189 & $0.485^{\mathrm{a}}$ & & 0.12 & $0.126^{\mathrm{a}}$ & $0.705^{\mathrm{a}}$ & & $0.173^{\mathrm{ab}}$ & & & & & \\
\hline & $252^{\text {cd }}$ & $0.267^{\mathrm{b}}$ & $0.185^{\mathrm{a}}$ & 0.195 & $0.486^{a}$ & $450^{\mathrm{a}}$ & $0.127^{\mathrm{a}}$ & $0.127^{\mathrm{a}}$ & $0.712^{\mathrm{a}}$ & $0.620^{\mathrm{b}}$ & $0.176^{\mathrm{a}}$ & & & & & \\
\hline & $260 \mathrm{~b}$ & $0.268^{\mathrm{ab}}$ & $0.181^{a}$ & 0.187 & $0.484^{a}$ & $0.455^{\mathrm{a}}$ & $0.125^{\mathrm{ab}}$ & $0.122^{b}$ & $0.709^{a}$ & $0.623^{\mathrm{ab}}$ & $0.176^{a}$ & $0.215^{\mathrm{a}}$ & 13.7 & $15.60^{a}$ & & \\
\hline & $258^{\text {bc }}$ & $0.275^{\mathrm{a}}$ & $0.180^{\mathrm{a}}$ & 0.182 & $0.482^{\mathrm{a}}$ & $0.450^{\mathrm{a}}$ & $0.124^{\mathrm{ab}}$ & $0.126^{a}$ & $0.71^{\mathrm{a}}$ & $0.625^{\mathrm{ab}}$ & $0.177^{\mathrm{a}}$ & $0.215^{\mathrm{a}}$ & 13.8 & $15.30^{\mathrm{a}}$ & 29. & $30.20^{c}$ \\
\hline & $0.282^{\mathrm{a}}$ & $0.262^{b}$ & $0.182^{\mathrm{a}}$ & 0.182 & $0.483^{\mathrm{a}}$ & $0.450^{\mathrm{a}}$ & $0.122^{\mathrm{ab}}$ & $0.125^{\mathrm{ab}}$ & $0.705^{a}$ & $0.630^{\mathrm{ab}}$ & $0.173^{\mathrm{ab}}$ & $0.210^{\mathrm{a}}$ & $13.700^{\mathrm{a}}$ & $15.35^{\mathrm{a}}$ & $29.150^{\circ}$ & ${ }^{c d} 30.25^{c}$ \\
\hline & 1.411 & 1.538 & 1.620 & 1.490 & 1.461 & 1.432 & 1.431 & 1.336 & 1.481 & 1.397 & 1.529 & 1.708 & 1.482 & 1.453 & 1.447 & 1.554 \\
\hline & 006 & - & - & - & - & & - & - & - & - & & - & - & - & 0.778 & 0.872 \\
\hline Significance & & NS & NS & NS & NS & NS & NS & NS & NS & NS & NS & NS & NS & NS & 舟 & \\
\hline \multicolumn{17}{|c|}{ ches } \\
\hline 1-4 nodes & $0.280^{f}$ & $0.310^{b}$ & $0.180^{\mathrm{ab}}$ & $0.175^{\circ}$ & $1.092^{\mathrm{a}}$ & $1.090^{\mathrm{a}}$ & $0.109^{a b c}$ & $0.110^{b}$ & $0.525^{\mathrm{a}}$ & $0.530^{\mathrm{a}}$ & $0.114^{c}$ & $0.118^{\mathrm{a}}$ & $9.40^{\mathrm{a}}$ & $9.60^{\mathrm{a}}$ & $24.255^{b}$ & b $22.150^{b}$ \\
\hline & $0.308^{e}$ & $0.290^{\circ}$ & $0.181^{\mathrm{a}}$ & $0.181^{\mathrm{ab}}$ & $1.100^{\mathrm{a}}$ & $1.095^{\mathrm{a}}$ & $0.108^{b c}$ & $0.112^{a b}$ & $0.530^{\mathrm{a}}$ & $0.530^{\mathrm{a}}$ & $0.115^{\mathrm{bc}}$ & $0.115^{\mathrm{a}}$ & $9.45^{\mathrm{a}}$ & $9.50^{\mathrm{a}}$ & $25.120^{\mathrm{a}}$ & $22.115^{b}$ \\
\hline & $364^{\circ}$ & 0.31 & $0.181^{\mathrm{a}}$ & $0.181^{\text {ab }}$ & $1.095^{\mathrm{a}}$ & $1.110^{\mathrm{a}}$ & $0.108^{b c}$ & $0.110^{b}$ & $0.527^{\mathrm{a}}$ & 0.53 & $0.114^{\circ}$ & 0.11 & $9.45^{\mathrm{a}}$ & $5^{\mathrm{a}}$ & & $23.125^{\mathrm{a}}$ \\
\hline & $392^{b}$ & $0.320^{\mathrm{a}}$ & $183^{\mathrm{a}}$ & 0. & $1.095^{\mathrm{a}}$ & 1.1 & $0.110^{\mathrm{ab}}$ & $0.115^{\mathrm{a}}$ & $0.520^{\mathrm{a}}$ & 0.5 & 0.1 & & 9.4 & & & \\
\hline & $0.420^{b}$ & $0.310^{b}$ & $0.181^{\mathrm{a}}$ & $0.178^{\mathrm{abc}}$ & $1.097^{\mathrm{a}}$ & $1.090^{\mathrm{a}}$ & $0.107^{c}$ & $0.115^{\mathrm{a}}$ & $0.520^{\mathrm{a}}$ & $0.530^{\mathrm{a}}$ & $0.118^{a b}$ & & $9.45^{\mathrm{a}}$ & & 23. & ${ }^{c} 22.160^{b}$ \\
\hline & $0.336^{d}$ & $0.315^{\mathrm{ab}}$ & $0.176^{b}$ & $0.176^{\mathrm{bc}}$ & $1.100^{\mathrm{a}}$ & $1.090^{\mathrm{a}}$ & $0.111^{\mathrm{a}}$ & $0.115^{b}$ & $0.518^{\mathrm{a}}$ & $0.530^{\mathrm{a}}$ & $0.120^{a}$ & $0.115^{\mathrm{a}}$ & $9.40^{\mathrm{a}}$ & & $23.250^{\circ}$ & ${ }^{c} 23.150^{\circ}$ \\
\hline & 339 & 1.332 & 1.431 & 1.655 & 1.469 & 1.435 & 1.352 & 1.572 & 1.452 & 1.438 & 1.674 & 1.449 & 1.472 & 1.489 & 1.4 & 1.543 \\
\hline & & 0.007 & - & - & - & ( & - & - & ( & - & 0.003 & ( & 刑 & - & 0.626 & 0.635 \\
\hline Significance & ( & ** & NS & NS & NS & & NS & NS & NS & NS & & NS & NS & NS & & \\
\hline
\end{tabular}

S-1 (season 1) and S2 (season 2); NS (Non- significant)

sections of canes. Satisha et al. (2008) reported that the $\mathrm{C} / \mathrm{N}$ ratio directly corresponds to the rooting ability of cuttings of rootstocks. The results of the present study also confirms the findings of
Mochioka et al. (2002) who found that the rooting ability of $V$. Kiusiana cuttings was poor due to excess of endogenous phenolics in shoots. Reduction in the rooting percentage of apical 
cuttings might be due to higher content of rooting inhibitors and lesser concentrations of auxins.

Among the different biochemical parameters analyzed, reducing sugar varied significantly in Dogridge during both the seasons with higher amount in 9-20 bud position, while it was reduced to maximum at the apical nodes. The same rootstock recorded maximum reducing sugar in the next season. Protein content was more in 1-16 nodes in Dogridge, whereas in 110-R rootstock no change in protein content was noted during the first year. The changes in phenolic compounds in both the rootstocks were noticed only during first year. Higher amount of phenol was recorded in the cuttings of Dogridge rootstock than in 110-R cuttings. In Dogridge rootstock, it was more in 1-16 nodes whereas in 110-R rootstock, it was higher in 1-12 buds only. Variation in starch content was recorded only in case of Dogridge rootstock, whereas there was no change in the starch content in $110-R$ rootstock. The concentration was more in 1-12 bud positions and thereafter, reduction was noticed in lateral buds. The same trend was observed for total carbohydrate content in Dogridge rootstock. The variations in the biochemical composition of different nodes of the canes might be due to the metabolic changes in the plant system during development of cuttings. Increased biochemical constituents in plant might beattributed to more sprout; more leaves, better photosynthesis, and in turn production of secondary metabolites like phenols (Satisha et al., 2007). Similarly, Coban (2007) also reported increased activity of polyphenol oxidase in Sultana, Round Seedless and Yalovalncisi during early stages after planting, followed by a decrease in activity after some time. The biochemical constituents in terms of reserve food material in cuttings play an important role in rooting. Reduction in rooting percentage of rootstock might be due to the availability of higher contents of rooting inhibitors and lower concentration of auxins. Phenol may play an important role in the rooting process of cuttings. Availability of higher phenol in Dogridge rootstock also associated with more root primordial and greater root length. The results of the present study on phenolic content are in agreement with our earlier studies (Somkuwar et al., 2011). Satisha et al. (2008) found a positive relationship between carbohydrates and nitrogen contents of rooting of stem cuttings.

Nutrient reserve in the canes of both rootstocks showed insignificant changes in different nodal segments (Table 4). Nitrogen content in Dogridge rootstock was more till $16^{\text {th }}$ nodes, while it was reduced in 17-20 nodes and was again increased in the apical portion of 21-24 nodes. However, difference in nitrogen content in different nodal sections of the same rootstocks during the next year of study was non-significant. In 110-R rootstock, nitrogen content was found to be increased from first node to $20^{\text {th }}$ node. The concentration then reduced towards the lateral shoot end. During the next year, though the differences were recorded for nitrogen content, the consistency in increasing the shoot length was not observed. The change in magnesium concentration in 110-R rootstock during the second year of study was recorded. Significant differences were recorded for Fe concentration in different nodal sections in both the rootstocks. The concentration was more till 16 bud positions, while it was reduced after $16^{\text {th }}$ nodes during both the season of study. The same trend was recorded in 110-R rootstock. Other important nutrient reserves did not show statistically significant differences at similar levels through the length of the canes. The differences among the contents of $\mathrm{N}$ and Fe could be influenced by rootstocks. The mechanisms behind the influence of rootstock on scion vigor and yield was due to its effects upon the scion by influencing the amounts of minerals taken up and translocated to the scion (Amiri et al., 2014). Basically, rootstocks are known to exert their effects through plant vigor and consistently have influence on leaf exposure, water and nitrogen availability at maturation (Baso et al., 2008). The results of the present study confirms the findings of Turkmen et al. (2011) who showed that canes of $140 \mathrm{Ru}$ rootstock induced a minor effect on its mineral content, which might play a role in their rooting capacity. Similarly, Satisha et al. (2007) stated that optimum C/N ratios in the mother vines of these rootstocks helped attaining better rooting percentages of hardwood cuttings.

The results of the present study suggested that the segment form 1 to $12^{\text {th }}$ inDogridge rootstocks and 1 to $16^{\text {th }}$ in $110-R$ rootstocks had better quality in terms of early bud sprout, better rooting percent, higher shoot length, shoot diameter and maximum biochemical compounds such as reducing sugar, proteins, total phenols, starch and carbohydrate contents. The cuttings made from these segments of both rootstocks might help in obtaining better establishment in field.

\section{Acknowledgment}

We thank Director, ICAR-National Research Centre for Grapes, Pune for providing the facilities to carry out the research work.

\section{References}

Boso, S., J.L. Santiago and M.C. Martinez: The influence of $110 R$ and $\mathrm{SO}_{4}$ rootstocks on the performance of scions of Vitisvinifera L., $\mathrm{cV}$. Albarino clones. Spanish J. Agric. Res., 6, 96-104 (2008).

Citadin, I., M.C.B. Raseira, F. Augustin, F. Herter, A.D. Campos and C.A.P. Silveira: Relation of peroxidase, 6-phosphoglucinolate dehydrogenase and phosphoglucoisomerase with endodormancy phase in peach, Abstract, $5^{\text {th }}$ International Peach Symposium, Davis, California, pp. 8-11(2011).

Coban, $H .:$ Determination of polyphenol oxidase activity during rooting in cuttings of some grape varieties (Vitisvinifera L). Asian J. Chem., 19, 4020-4024(2007).

Dardeniz, A., Z. Gokbayrak, N.M. Muftuoglu, C. Turkmen and K. Beser: Cane quality determination of $5 \mathrm{BB}$ and $140 \mathrm{Ru}$ grape rootstocks. Europ. J. Hort. Sci., 73, 254-258 (2008).

Dardenı, A., N.M. Muftuo Lu, Z. Gokbayrak and M. Firat: Assessment of morphological changes and determination of best cane collection 
time for 140 Ruggeri and 5BB. Sci. Hort., 113, 87-91(2007).

Hartmann, H.T., D.E. Kester and F.T. Davies: Plant propagationprinciples and practices: Prentice Hall, New Delhi, India (1993).

Hunter, J.J., C.G. Volschenk, D.J. Roux, G.W. Fouche and L. Adams: Plant material quality: ARC Infruitec-Nietvoorbij, Private Bag X5026, 7599 Stellenbosch, South Africa, p. 18 (2004).

Lowry, O.H., N.J. Rosenbrough, A.L. Farr and R.J. Randall: Protein measurement with the Folin phenol reagent. J. Biolog. Chem., 193-265 (1951).

Mochioka, R., Y. Oder and M. TsuBakimota: Relation between the rooting difficulty of cuttings and contents of phenolic compounds in shoots of Japanese wild grape Vitiskiusiana Momiyama. J. Asev. Japan., 13, 2-8(2002).

Mohammad, E.A., E. Fallahi and M. Safi-Songhorabad: Influence of rootstock on mineral uptake and scion growth of 'golden delicious' and 'royal gala' apples. J. Plant Nutr., 37, 16-29 (2014).

Sadashivam, S. and A. Manickam: Biochemical Methods. $2^{\text {nd }}$ Edn., New Age International Pvt. Ltd., (1992).

SAS, 9.3 T S Level 1 M0. Copyright ( ) 2002-2010 by SAS Institute Inc., Cary. NC, USA. Licensed to Indian Agricultural Statistics Research Institute.

Satisha, J., D.P. Oulkar, K. Banerjee, J. Sharma, A.G. Patil, S.R. Maske and R.G. Somkuwar: Biochemically induced variations during some phenological stages in Thompson seedless grapevines grafted on different rootstocks. S. Afr. J. Enol. Vitic., 34, 36-45 (2012).

Satisha, J., P. Raveendran and N.D. Rokade: Changes in polyphenol oxidase activity during rooting of hardwood cuttings in three grape rootstocks under Indian conditions. S. Afr. J. Enol. Vatic., 29, 94-97 (2008).

Satisha, J., S.D. Ramteke and G.S. Karibasappa: Physiological and biochemical characterisation of grape rootstocks. S. Afr. J. Enol. Vitic., 28, 163-168 (2007).

Sharma, J., A.K. Upadhyay, D. Bande and S.D. Patil: Studies on black leaf symptom development and its impact on nutrient profile and fruitfulness in Thompson seedless grapevines grafted on Dogridge rootstock. Indian J. Hort., 67, 156-160 (2010).

Singh, M. and J.K. Sharma: Effect of rootstocks on disease intensity of Perlette grape vine. Haryana J. Hortic. Sci., 34, 234-235 (2005).

Sivaci, A.: Seasonal changes of total carbohydrate contents in three varieties of apple (Malus sylvestris Miller) stem cuttings. Scientia Hort., 109, 234-237(2006).

Somkuwar, R.G., D.D. Bondage, M.S. Surange and S.D. Ramteke: Rooting behaviour, polyphenol oxidase activity, and biochemical changes in grape rootstocks at different growth stages. Turk. J. Agril. Fore., 35, 281-287(2011).

Somkuwar, R.G., J. Satisha, S.D. Ramteke and K. Mundankar: Effect of different rootstocks on graft success in Flame Seedless grapes. J. ProdProt., 2, 63-64(2006).

Somkuwar, R.G., J. Satisha, S.D. Ramteke and J. Sharma: Root distribution, partitioning of dry matter and nutrient uptake in Thompson seedless grapes (Vitisvinifera L.) grafted on different rootstocks. Indian. J. Agril. Sci., 79, 669-673 (2009).

Turkmen, C., A. Dardeniz, N.M. Muftuoglu, Z. Gokbayrak and A. Kabaoglu: Nutrient contents of 140 Ruggeri rootstock canes in dormant season. J. Animal Plant Sci., 21, 730-733 (2011). 